\title{
Tracing the Sources of Pollution of Wells and Karst springs Supplying Water to the City of Ragusa, South-Eastern Sicily
}

\section{Rosario Ruggieri}

Assessorato Infrastrutture e Mobilità, Sicily Region Hyblean Center for Speleo Hydrogeological Researches, University of Nova Gorica, Slovenia

Study Area: Ragusa, Italy

Coordinates: $36^{\circ} 56^{\prime} \mathrm{N} \quad 14^{\circ} 45^{\prime} \mathrm{E}$

Key words: Sicily, Hyblean plateau, karst springs, pollution, tracer tests.

\section{Abstract}

The present study deals with the pollution which has occured in two important karst springs, supplying the acqueduct of Ragusa city in Italy. Both springs show higher values of ammonia and the presence of pathogenic bacteria, elements ascribable to wastewater of animal origin. This investigations identified a number of farms present within the springs protected areas which likely have caused the pollution. At these farm was imposed by ordinances to build adequate storage tanks for the animal wastewater. Paradoxically, the construction of such tanks led to a further worsening of the state of pollution, as the latter from episodic, linked to rainfall, became continuous due to the overflowing of wastewater from the tanks never emptied, as it was ascertained. A geological and geochemical study, preparatory to the execution of tracer tests, allowed a hydrogeological characterization of the recharge area and the definition of the hydrologic regime of the springs, that in this case, resulted as interconnected. Follow-up tests with fluorescent tracers, carried out on a few farms, were then interrupted due to the non-cooperation from one of the farm owners. From that moment on, every research for the origin of the pollutant gets stop and the situation gets worse, both in terms of environment and for the resulting pollution of two municipal drinking water wells placed at the confluence of the Ciaramite stream valley with the Irminio river. After passing 3 years of the polluting event, despite the ordinances issued by the City Hall towards a number of livestock farms who did not comply with the collection of waste and its disposal, as a result the collectivity have assisted to the loss of a spring and the ecological degradation of the Ciaramite stream valley.

Author:info@cirs-ragusa.org 


\section{Introduction:}

In the month of September, 2010 technicians of the Ragusa Municipality Water Service, Italy detected the presence of water pollution in the Oro and Misericordia springs. They warned both the Genio Civile di Ragusa Regional Office, responsible for licensing and authorizations of public waters, and the Environmental Protection Agency (Arpa) who monitors the quality control of surface and groundwater.

Following the first sampling and analyses which authentically detected the presence of pollutants beyond the threshold permitted by the Drinking Water Regulations (in particular $\mathrm{NH}_{4}$ ), the Municipality excluded the water of the aforementioned springs from the city aqueduct, while trying to identify and resolve the cause of that pollution. Meanwhile, the judicial authority of Ragusa started an investigation with the counsel of Genio Civile di Ragusa and the Arpa.

The surveys and inspections carried out in the springs' recharged area detected the presence of 12 potential sources of pollution from livestock farms (herd of cattle) which were not fulf illing the laws regarding the storage of organic manure and sewage collection. The notif ications of such violations of the law lead to the issue of complaints and ordinances that required farms to put in place statutory requirements regarding the collection and processing of cattle manure. At the same time a judicial/ administrative inquiry began and hydrogeological investigations were initiated by the Water Section of the Genio Civile di Ragusa a water quality monitoring was started by the ARPA (Regional Agency for Environmental Protection) and the ASP (Public Hygiene Laboratory), respectively, to evaluate the chemical and microbiological contaminations.

The above surveys, which have been described below, are aimed with the hydrogeological characterization of the springs regime and recharge area with their constant monitoring of chemical and microbiological activities, and to state a program of tracer tests, aiming to identify the causes of pollution of the aquifer drained by the aforementioned springs, which partially carried out in the later stage.

\section{Geographic and geological context:}

The area of investigation (Fig. 1) is located in the Hyblean Mountains in South-Eastern part of Sicily of Italy. This is an extensive plateau with the highest elevation of 10oom above the sea level, in its Northern sector (Mount Lauro carapace), sloping towards the East and South to the sea level, while to the West with a stair case pattern is connected with the Vittoria-Gela plain. From the geostructural point of view, the plateau constitutes a foreland sector which was slightly deformed during the Sicilian-Maghrebian chain orogeny westward and northward, overthrusted by the Gela nappe (foredeep sector), to the East connected with a series of stair casing faults with the Ionian abyssal plain, southward emerged in the Maltese and Pelagian islands (Pelagian Block).

The South-Western sector of the Hyblean Plateau, where the area of investigation is located which is dominated by carbonates of the Ragusa Formation (Rigo \& Barbieri, 1959; Grasso et al., 1992) made by two members: the Leonardo Member constituted by an alternation of calcisiltites, calcilutites, marls and marly limestones, with thickness not less than 10om and of Upper Oligocene age; the Irminio Member, of Lower Miocene age, constituted by calcarenites, calcarenites and marls limestone, with thickness more than 1oom.

\section{The hydrological and Karst features of the South-Western sector of the Hyblean Plateau:} Over the plateau, the principal aquifers are associated with the Ragusa Formation carbonates. A partly conf ined aquifers occur within the Irminio Member at depths of about 100-150 m. A deeper and better 


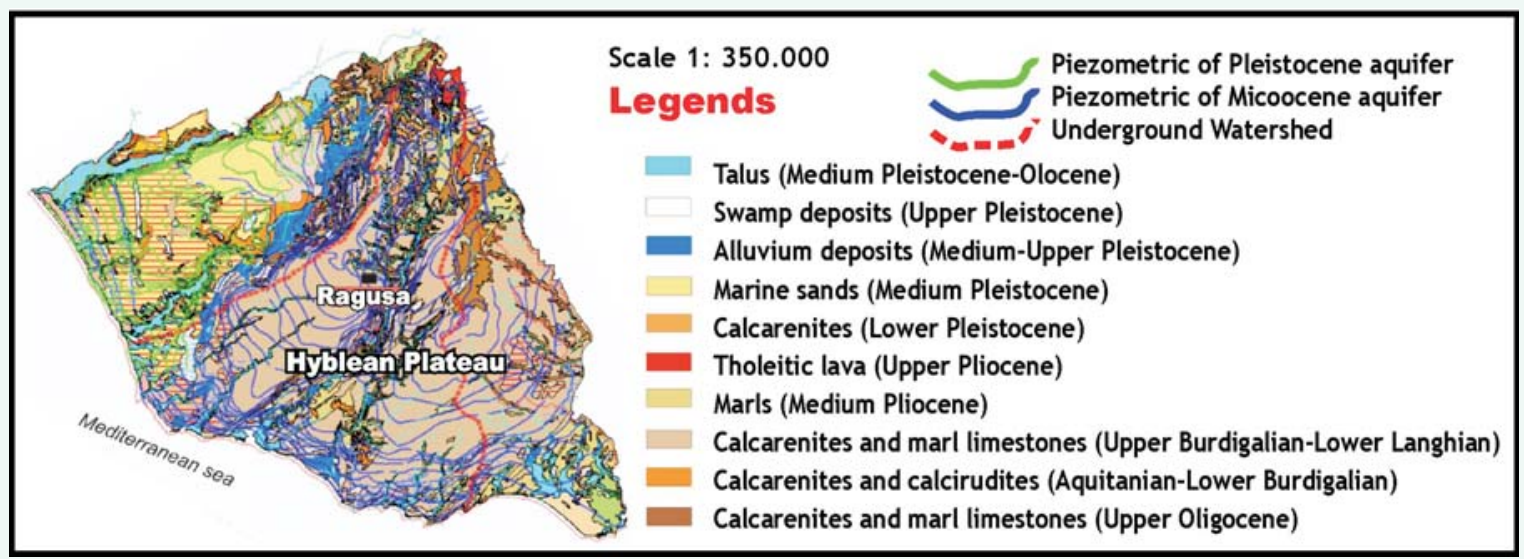

Fig.- 1: Main hydrogeological basins and watersheds (hatched red lines) of the central-southern sector of the Hyblean Plateau, with: green lines showing groundwater piezometric levels of the quaternaty sandcalcarenitic aquifer, blue lines groundwater piezometric levels of the miocenic limestone aquifer (modif ied from- Ruggieri, 2005). The legend reports the main lithological terrains outcropping in the basin.

confined aquifer within the Ragusa Formation is present in the Leonardo Member. Permeability is linked to secondary fracture porosity, because both carbonates and marls show a low inter-granular porosity. Locally the occurrence of important regional tectonic structures brings the two aquifers into hydraulic contact and affects a significant hydraulic pressure, which manifests in the emergence of artesian springs from these deeply buried aquifers.

The vulnerability of the carbonates aquifers is high, especially when not capped by clayey marls and even more when they form the exposed karst surface. Karst dissolution along the fracture systems of the Ragusa Formation carbonates, started at the end of the Miocene and has continued to develop in exposed areas throughout the Pliocene and Quaternary (Ruggieri \& Grasso, 200o).The gradual uplift of the plateau has also created the favourable conditions for generating a wide variety of karst landform at levels gradually decreasing from the upstream to the current coastline. The karst water circulation has moved gradually in depth, linked to the Pleistocene-Holocene tectonic uplifting of the plateau, connecting the level of the water resurgences to the local base valley erosion or, close to the coastline, to the sea base level.

\section{General piezometric framework:}

The survey of phreatimetric data, has allowed the reconstruction of piezometric surface and groundwater flow regime of the entire province of Ragusa. Thus, the charged areas of the hydrogeological South-central complex, bounded by two major water sheds as well as the three main hydrostructures were def ined. In this regard, the area covered in this report falls within the area of the central hydrogeological basin consisting of a carbonate block degrading towards the South-West deeply etched in correspondence with the Irminio River. This hydrogeological basin has a first aquifer in the series of calcarenitic layers of the Irminio Member, at depths of between $100-150 \mathrm{~m}$, which is followed by a separate variable of thickness layers of marls and clays, a deeper conf ined aquifer in the limestone-marl series of the Leonardo Member. In such a basin, two hydrogeological substructures are identif ied and in one of these, the Petraro-Biddemi-Irminio hydrokarst system, the area of recharge of the polluted springs falls. 


\section{Hydrological regime of springs and regulations:}

Oro and Misericordia springs, exist at about 580m apart from each other. Oro is located on the left slope of the Misericordia valley at $555 \mathrm{~m}$ asl, $2 \mathrm{~m}$ (approximate) above the water course of the Misericordia stream, where as Misericoordia spring is at an altitude of 545 meters on the left side of a short incision leading in the above mentioned valley (Fig. 2). Oro cave-spring is constituted by a conduit developed along a fracture which is extended approximately 3om, terminating in a sump, but the Misericordia is developed along a conduit, long a dozen of meters blocked by a landslide.

In the Fig.3 (line-diagram) some distinctive features of the two springs related to the variability and complexity of the circulation systems in fractured-karst limestone has been highlighted. In particular, the diagram, which relates to the rain fall for the period January-November 1996, indicating

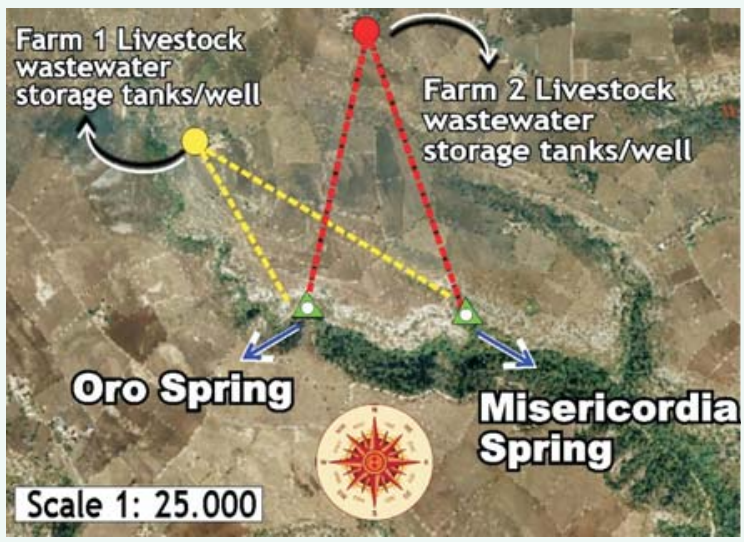

Fig. 2 - Location of Oro and Misericordia springs northward of Ragusa and respective Linear distances from 2 Farm wastewater tanks to the springs the discharges of the Oro spring characterized by a cyclical decline with peak flows and values close to zero, typical of a siphon emptying mechanism. Nevertheless, the discharge curve relative to the Misericordia spring, indicating a rapid decrease from high to small values, typical of a water flow concentrated in karst conduits (free-flow or flow conduit aquifer), which follows a stretch to a milder slope that characterizes a spread flow over a network of karstif ied fractures (diffuse flow aquifer).

In the Oro spring, observations conducted over a decade, endorse the above mentioned behavior with intermittent cyclical peak flows, not always connected to rainfall events, with phases of the discharge close to zero. In this context, the variability of discharge ranges between about 50-10o $1 / \mathrm{s}$ and $\mathrm{ol} / \mathrm{s}$, with an average discharge during theyears of about 10-15 $\mathrm{l} / \mathrm{s}$.

In the Misericordia spring, whose annual average discharge is about $20-40 \mathrm{l} / \mathrm{s}$, the range of discharge is between $150-200 \mathrm{l} / \mathrm{s}$ during overflow with rapid decreasing discharges in relation to the performance of rainy and dry season periods. The above springs supplying the city of Ragusa since 1996 are formally preserved by the creation of protected areas, including both the recharge area and the buffer zones for quality purposes.

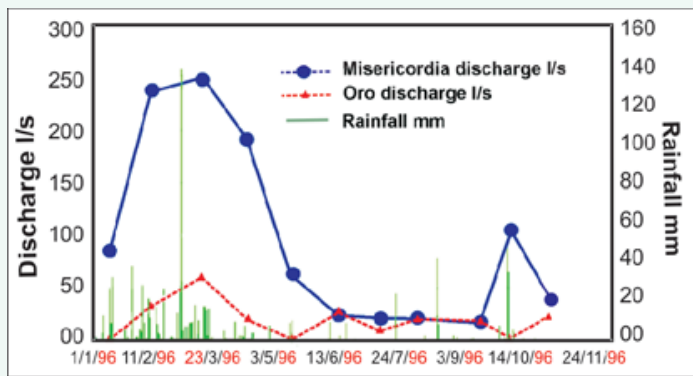

Fig. 3 - Diagram of comparison Oro Misericordia springs discharge / rainfall (January-November '96)

\section{Protocol for Investigations:}

Following some official formalities in the matter of public water, an investigation protocol was planned concerning the hydrogeological characterization of the area finalized and to cary out tracer tests for detecting the causes of the pollution of the springs.

\section{Hydrogeological investigation:}

The hydrogeological investigation involved the detailed reconstruction of piezometric surface and groundwater flow regime of the springs recharge area 
for the identification of groundwater flow directions and its watersheds. The above survey was therefore carried out in situ by measuring the water levels of the drilled wells, belonging to the farm owners. The subsequent processing of data allowed the def inition of the aforementioned piezometric levels, adjusted according to the valley depressions and taking on account of the presence of some apparent anomaly measures probably caused by the lateral recharge effects of the overflows in the karst conduits following the rainy days. On the map (Fig. 4), the main directions of groundwater flow and watersheds are shown with respect to the springs recharge area, the latter indicated with green triangles, as resulted from the above mentioned survey.

\section{Chemical and microbiological monitoring:}

The monitoring of chemical contents, revealed the presence of high values (above than the threshold values of the regulations) of $\mathrm{NH}_{4}, \mathrm{~K}, \mathrm{Na}$ and $\mathrm{Cl}$ (Fig. 5), while the microbiological analysis showed the presence of salmonella, a pathogenic bacteria. In particular, the time series analysis pointed out that the pollution of Oro and Misericordia springs, appearing for the first time in September 2010, the levels of $\mathrm{NH}_{4}$ in late 2010 decreased, and disappeared until April 2011; then pollution appeared again in May 2011, being persistent from then on specially in the Oro spring (Fig. 6). The pollution of the springs, from May 2011, was independent from the weather conditions, unlike the precedent period where the rains had triggered it and was conveying widely scattered waste water into groundwater, especially on the ground without any protection. The rainfall at the end of 2011, had, however, produced only a dilution effect of the levels of contamination, which then, in periods of low rainfall, returned to high values.

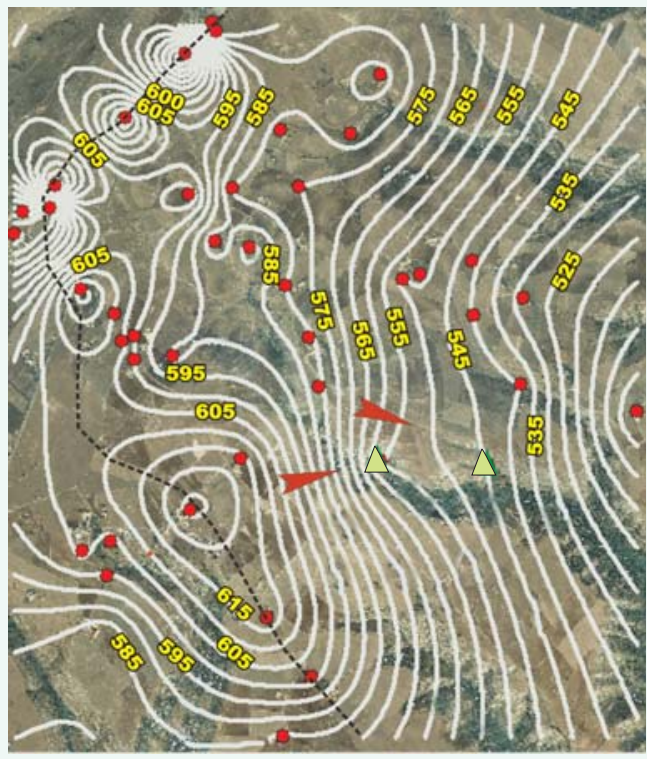

Fig. 4 - Groundwater piezometric levels, in the recharge area of the Oro and Misericordia springs (green triangles) and wells (red spots)

The contemporary state between the reappearance of pollution in the springs and the period of realization of the manure and sewage collection tanks that were made by the farmers, following the

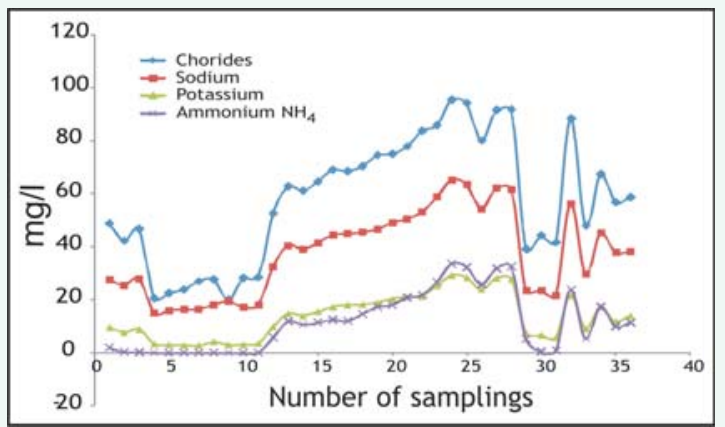

Fig. 5 - Variation of ions (Cl, Na, K \& Nh4+) in the water of Oro spring due to the pollution instructions issued by the Ragusa Municipality should be emphasized, with the high concentrations of the pollutants, prevailed the assumption of a constant loss from an underground storage tank, which was continuously fed by wastewater due to cattle breeding. This loss would create a persistent stream of liquid manure, which seeping through the fractured ground, would be conveyed quickly to the karst conduits of the aquifers drained by the springs.

\section{Tracing tests:}

Based on the results of chemical and hydrogeological investigations, the area where to investigate the causes that led to the pollution of the 
Fig. 6 - Oro spring: correlation Rainfall $\mathrm{NH}_{4}+$

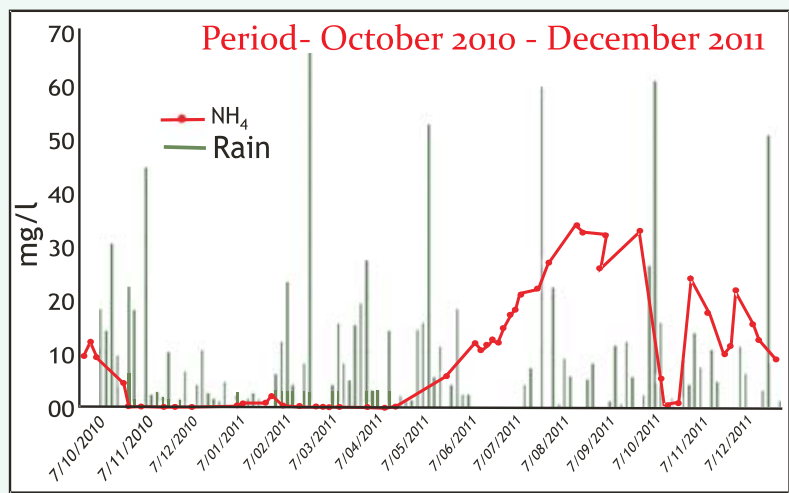

Oro and Misericordia springs was delimited. Once these points of potential wastewater leakage were identified, the Genio Civile and Arpa proposed to the Municipal of Ragusa to initiate the tracing tests (USEPA, 1988, 2003; Field, 2003; Benischke et al., 2007; Goldscheider et al., 2008; Kogovšek \& Petriè, 2010) using safe non toxic artif icial dye tracer (Behrerns, 2001) in order to identify which of these points was the cause for the propagation of the pollution towards the springs. The administration as a result of this proposal organized a meeting with the farmers to ask their collaboration for the execution of the aforementioned tests with the injection of a non toxic artif icial tracer in the tanks and /or in the surrounding areas of their farm. Once the farmers' consent was obtained, the Genio Civile and Arpa structured a program of investigations subdivided in a preliminary monitoring phase, a second phase related to the tracing test, and a subsequent monitoring to detect the tracer, as described below.

\section{First Phase of investigation:}

During the first phase of investigation, tests were intended to monitor the initiation of pollution due to the chemical resources. In addition, the daily measures of discharges and the survey amount of rainy days, have aimed to draw diagrams of comparison concerning the hydrological regime of the two springs and their correlations with the chemical indicators of pollution.

\section{Springs' regime}

The comparison between the discharges of the two springs, measured before and during the tracer tests, herein after described, correlated with the rainy events, shows in the line diagram of Fig. 7 the following points:

1. The discharges of the Misericordia spring are bigger than the Oro Spring discharges until on $23^{\text {rd }}$ of March, with peaks, correlated with the rainy events, which quickly decrease with the rapid emptying of the karst

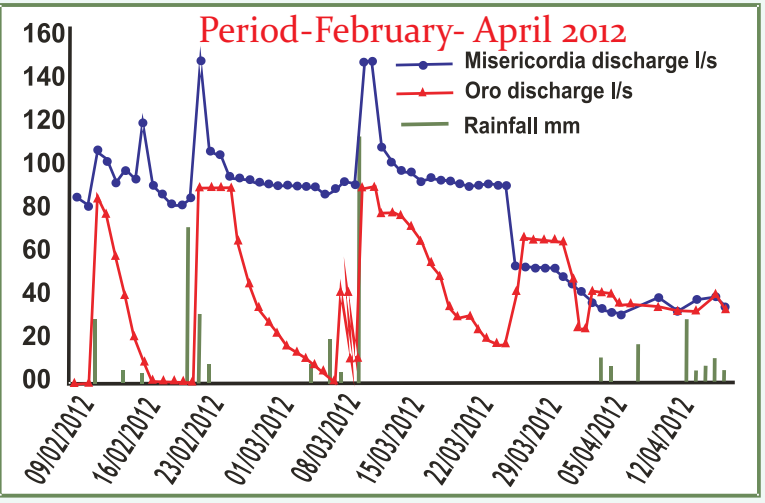

Fig.-7: Comparison Oro- Misericordia springs' discharge conduits, then assuming a constant regime until the successive rainy event.

2. The Oro spring discharge peaks appears coinciding with the rainy events but, unlike of the Misericordia spring, with a less accentuated decrement until discharge values come close to zero.

3. Both the springs show fast responses against the rain with peaks of rainfall quickly attained during the 24 hours from the beginning of the atmospheric events.

4. Starting from the $23^{\text {rd }}$ of March a singular phenomena appears with a fast decrease of the Misericordia spring discharges opposing to the same extent fast increase of the Oro spring discharges until on $27^{\text {th }}$ March, afterwards for both the springs a phase with constant flow follows 
with values of discharges this way bigger for the Oro, then a gradual decrease with discharges attested on almost equal values for both the springs.

From the above observations the following could be concluded: the Misericordia and Oro springs both are characterized by a network of conduit-flow streams. These two systems of conduits are linked by a sump, which as the underground divide moves in the karst system, allows the emptying flow phase of the Oro spring with the water pouring off to the Misericordia spring.

\section{Determination of parameters for hydrological tracer tests and estimated time of arrival and tracer's quantity:}

The proposed and performed tests consisted of the injecting of an artificial dye tracer (sodium fluorescein and/or Tinopal CBS-X) at a point absorber (wastewater tanks) and the following daily monitoring of water emerging from the Oro and Misericordia springs using activated charcoal bags, in order to verify the possible detection of the tracer.

For the assessment of the likely time of arrival of tracer at the springs, three possible water flow velocities, equal to $133 \mathrm{~m} / \mathrm{h}, 200 \mathrm{~m} / \mathrm{h}$ and $72 \mathrm{~m} / \mathrm{h}$ (Table.1) were considered as a first approximation. The first two resulting from surveys and studies of pollution incidents that occurred in the hyblean area(Ruggieri, 1997), the third one mentioned in the literature by Field (2003), for testing a karst flowing conducts of solution, resulting from a statistical calculation of about 3000 tests carried out in the world, used as a starting pointing designing a sampling program.

Tablele. 1 - Linear distance - calculated arrival time to the springs per flow speeds (V) equal to $72 \mathrm{~m} / \mathrm{h}$, $133 \mathrm{~m} / \mathrm{h}$ and $200 \mathrm{~m} / \mathrm{h}$

\begin{tabular}{|c|c|c|c|c|c|c|c|c|}
\hline \multirow{2}{*}{$\begin{array}{l}\text { Live stock } \\
\text { wastewater } \\
\text { storagetanks }\end{array}$} & \multicolumn{4}{|c|}{ ORO spring } & \multicolumn{4}{|c|}{ MISERICORDIA spring } \\
\hline & Distance & $V_{72} \mathrm{~m}-\mathrm{h}$ & $\begin{array}{l}\text { V1331 } \\
\text { Time }\end{array}$ & V200m-h & Distance & $\mathrm{V}_{72} \mathrm{~m}-\mathrm{h}$ & $\begin{array}{l}\text { V1331 } \\
\text { Time }\end{array}$ & $\begin{array}{l}\text { V20om-h } \\
\text { s) }\end{array}$ \\
\hline Farm 1 & 726 & 10 & 5.46 & 3.63 & 1160 & 16.1 & 8.72 & 5.8 \\
\hline Farm 2 & 1030 & 15.69 & $7 \cdot 74$ & 5.15 & 1090 & 15.15 & 8.19 & 5.45 \\
\hline Farm 3 & 1234 & 17.14 & 9.27 & 6.17 & 1547 & 21.48 & 11.63 & $7 \cdot 73$ \\
\hline Farm 4 & 1527 & 21.21 & 11.48 & 7.63 & 1858 & 25.8 & 13.97 & 9.29 \\
\hline
\end{tabular}

Therefore, in relation to the different distances of the points of injection from the springs, measured with orthophoto cartography, and using the aforementioned flow rate, the relative probable arrival times given in Tablele. 1 were calculated. For the calculation of the quantity of tracer to be injected, reference was made to four different formulas, applicable in situations of flowing solution karst conduits, in order to have a range of results, possibly comparable, from which to select the data quantifying the first approximation of departure, in relation to the hydrogeological situations encountered.

\section{Tracer test with sodium fluorescein:}

After establelishing the background concentrations at the springs with blank sample with the placement of charcoal bags at the springs, on March 26,2012 the tracer test started with the injection of a given quantity of sodium fluorescein in the hole trench containing the waste water tank of the Farm 1, which was the closest to the springs than the other farms selected for the tests (Fig. 2). Required quantity of tracer to inject, were standarized from the prescribed formulas (Table.-2). As a precautionary measure it has also been monitored to use the quantity falling within the range determined by the formulas of Käss (1998) and Martel (1913). In this way, an amount equal to about 
500 grams of sodium fluorescein, after being dissolved in water, was gradually injected into the excavation and simultaneously flushed with a quantity of water equal to $8 \mathrm{~m}^{3}$ in about 60 minutes, corresponding to a discharge of $2,2 \mathrm{l} / \mathrm{s}$ (Figs. 8a,b).

Table. 2 - Quantity of tracer to inject into the Farm 1's tank, calculated with the various formulas based on water flows velocity, in karst conduits and/or fracturated zones, equal to $200 \mathrm{~m} / \mathrm{h}$.

\begin{tabular}{|lcllll|lllll|}
\hline \multicolumn{6}{|c|}{ ORO $\left(\mathrm{Q}=0,042 \mathrm{~m}^{3} / \mathrm{s}\right)$} & \multicolumn{5}{c|}{ MISERICORDIA $\left(\mathrm{Q}=0,055 \mathrm{~m}^{3} / \mathrm{s}\right)$} \\
\hline Farm & $\mathrm{D}$ & Aley & Käss & Martel \& & Vigna \& & $\mathrm{D}$ & Aley & Käss & Martel & Vigna \& \\
& $(\mathrm{m})$ & $\mathrm{M}(\mathrm{kg})$ & $\mathrm{M}(\mathrm{kg})$ & $\begin{array}{l}\text { Fourier } \\
\text { M }\end{array}$ & Marchiolatti & $(\mathrm{m})$ & $\mathrm{M}(\mathrm{Kg})$ & $\mathrm{M}(\mathrm{Kg})$ & $\mathrm{M}(\mathrm{Kg})$ & Marchiolatti \\
& & & & $\mathrm{M}(\mathrm{kg})$ & & & & & $\mathrm{M}(\mathrm{kg})$ \\
\hline Farm 1 & 726 & 1.1 & 0.363 & 0.030 & 1.95 & 1160 & 5 & 0.58 & 0.064 & 2.824 \\
\hline
\end{tabular}

\section{Springs monitoring phase:}

The monitoring was limited to the qualitative detection of the presence of tracer with Wood's lamp, with a sampling program of collecting charcoal bags at the springs with intervals of 24 hours. In this regard, within 12 hours of the tracer injection on March 26, 2012 a single visual observation on the possible arrival of the dye tracer at the springs was carried out, then after 24 hours the first bag was taken in both sources. The process continued for the every 24 hours during the following days.

The preparation and observation of the samples with ultraviolet light occurred at the ARPA laboratories . From the above observations the following

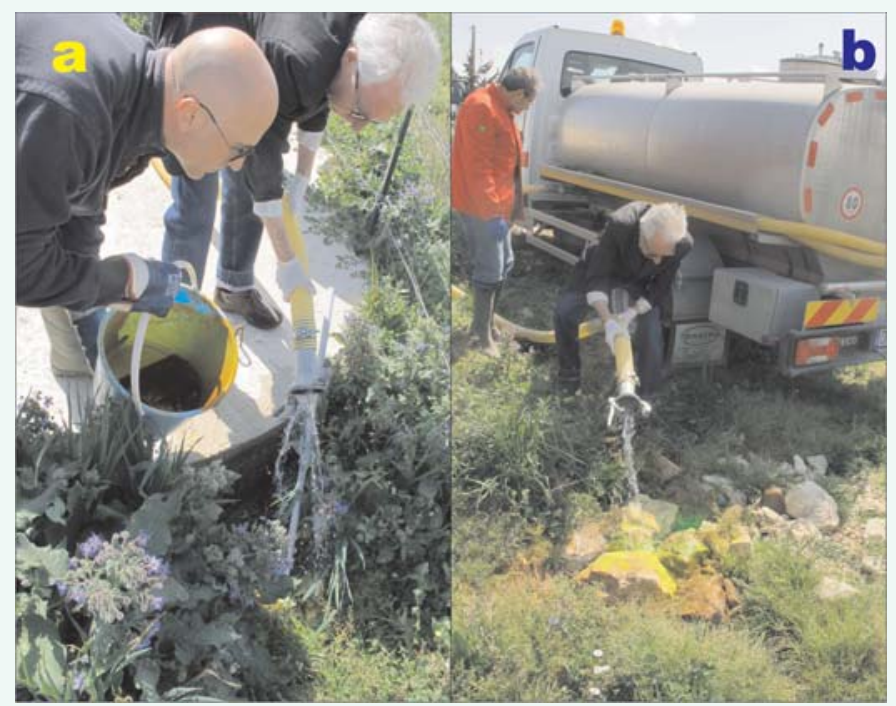

Fig.-8a,b: Injection and flushing of the dye tracer in the trench conclusions were drawn:

1. fluorescein injected between $11-11.30$ am on March 26 was detected with the charcoal bag taken after 24 hours of placing in the Oro spring;

2. the quantity of fluorescence reached its maximum between 72 to 96 hours after placing, subsequently perceptibly it began to decrease, such as showed by the eluted samples.

3. in the Misericordia spring the fluorescence was detected with the third charcoal bag, between 48 to 72 hours, remaining constant in intensityalso in the subsequent samples;

4. the fluorescence intensity at the Oro spring was always greater than that detected at the Misericordia spring.

\section{Tracer test with Tinopal CBS-X:}

As the presence of fluorescein ended in the springs, and then after the initial condition of chemical concentration was checked with blank samples, on 23 May 2012 the second test with the injection of Tinopal CBS-X began. This time into the wastewater tank of Farm 2, distant from the Oro and 
Misericordia springs 1030m and 1090m respectively (Fig. 2). In the days following the injection of the tracer, no evidence of its presence in the water flowing from the springs. was noticed. This evidence if on one hand would give indications on the seal of the tank, on the other hand, however, fails to answers on the conditions of impermeability of the excavation which host the tank in all those situations of external pouring off of the wastewater which, as aforesaid, seem to be the most common condition. In this regard, the farmer did not want neither that the tracer was poured outside the tank, nor that an equal quantity of tracer was injected into a drilled well distant from the tank about $20 \mathrm{~m}$, since both the situations were not specif ically mentioned in the testing plan made by the Municipality.

\section{Results and conclusions:}

Since the possibility to carry out other tests at the moment was denied by the farmers, and waiting that the Municipality takes a policy decision in the public interest on how to solve this situation,, the following conclusions have been based on the investigations so far carried out:

1. The diagram of comparison rainfall-discharges shows that, although the springs have different but contiguous recharge areas, they belong to the same hydrological karst system and interconnect each other as the underground divides vertically move, in relation to the rainfall seasonal regime. This fact allows the interchange of waters and the consequent diffusion of the pollution from one spring to the other. The hydraulic and karst hydrological condition which control this springs' singular behavior is still not clear and at this regard further investigations, with the support of automatic record equipment (for the monitoring of levels at the springs and some chemical parameters), are being conducted to support the realization of future quantitative tracer tests.

2. In relation to the lithological, structural and hydrogeological high vulnerability conditions, the area within which the pollution of the Oro and Misericordia springs occurred was delimited.

3. In this area some farms had been identified, from where, in relation to the encountered situations (not airtight tanks and excavation) the inf iltration of matter into the ground might getting possible, hence the aquifer getting polluted.

4. Tests with dye tracer (sodium fluorescein) injected and flushed into the tank excavation of the Farm 1, had given positive results within 24 hours of the injection in the Oro spring and within 72 hours in the Misericordia spring .

5. Although the second test with Tinopal CBS-X tracer, injected into the tank of Farm 2, failed to reveal any positive evidences, and the further tests (in drilled well and / or outside the tank) were stopped, it remain inconclusive.

Finally as stated earlier, in consideration of the high vulnerability of the springs' recharge area, it cannot be excluded that additional wastewater seepage might occurcaused by other farms.

It follows that, regardless of how more or less normally the farms carry out the treatment of sewage and manure of livestock, the present practice is definitely not compatible with the legislation and regulatory requirements governing the areas of protection of drinking water. For this reason, the Municipality of Ragusa must assume responsibility for deciding whether to tolerate the presence of these farms and therefore give up to the waters of the springs with a simultaneous increase of costs to replace the polluted waters with new resource from drilled wells, or find alternative solutions, such as the removal and treatment of wastewater stored in the tanks, at their own expense, at the municipal sewage treatment plant or alternatively, with the planning and construction of a biogas conversion plant. 


\section{Acknowledgements:}

I would like to thank to the techncians of the Municiplaity of Ragusa who supported me both in the first phase of field investigation and during the tracer tests.

\section{References:}

Benischke R., Goldscheider N. \& Smart C.C. (2007): Tracer techniques. In: Goldscheider N. \& Drew D. (Eds.) Methods in Karst Hydrogeology. International Contributions to Hydrogeology. Taylor \& Francis, London, UK: 147-170.

Behrens H., Beims U.,·Dieter H.,. Dietze G., Eikmann T., ·Grummt T., Hanisch H., ·Henseling H., Käß W., Kerndorff H., Leibundgut C., Müller-Wegener U., Rönnefahrt I.,. Scharenberg • B.,. Schleyer R.,.Schloz · W. \& Tilkes F (2001): Toxicological and ecotoxicological assessment of water tracers. Hydrogeology Journal, 9:321-325.

Field M. S. (2003): A review of some trace-test design equations for tracer-mass estimation and sample-collection frequency. Environmental Geology, 43:867-881.

Goldscheider N., Meiman J., Pronk M. \& Smart C. (2008): Tracer tests in karst hydrogeology and speleology. International Journal of Speleology, 37 (1):27-40.

Grasso M. \& Ben-Avraham, Z. (1992): Magnetic study of the Northen margin of the Hyblean Plateau, SouthEastern Sicily: structural implications. Annales Tectonicae, $\mathrm{VI}(2): 202-213$.

Grasso M., Pedley H.M., Maniscalco R. \& Ruggieri, R. (200o): Geological context and explanatory notes of the "Carta Geologica del settore centro-meridionale dell'Altopiano Ibleo". Mem. Soc. Geol. It., 55: 45-52.

Käss W. (1998):. Tracer technique in geohydrology, Balkema, Rotterdam, 581 p.

Kogovšek J. \& PetrièM., (2010): Tracer tests as a tool for planning the monitoring of negative impacts of the Mozelj landfill (Se Slovenia) on karst waters. Acta Carsologica,39/2:301-311.

Martel E.A. (1913). Sur les expériences de fluorescéine à grandes distances. Comptes Rendus de l'Académie de Sciences, 157:1102-1104.

Rigo M.\& Barbieri R. (1959):. Stratigrafia pratica applicata in Sicilia. Bollettino del Servizio Geologico d'Italia, 80: $1-92$.

Ruggieri R. (1997): Problematiche di protezione della risorsa idrica in rocce fessurate e carsificate: la fiumara di Modica e la sorgente Salto di Lepre ( $\mathrm{Rg})$, un caso emblematico di inquinamento negli Iblei. Atti del $2^{\circ}$ Congresso Regionale dei Geologi di Sicilia, Erice 2-4 ottobre 1997, pp. 91-102.

Ruggieri R. (2005): Il sistema idrogeologico del settore centro-meridionale Ibleo (Sicilia sud-orientale). Atti del Convegno"L'acqua che berremo" (2002-2004). Speleologia Iblea, 11: 17-37.

Ruggieri R. \& Grasso M. (200o): Caratteristiche stratigrafiche e strutturali dell'altipiano Ibleo e sue implicazioni sulla morfogenesi carsica. Speleologia Iblea, 8:. 19-35.

UNITED STATES ENVIRONMENTAL PROTECTION AGENCY (1988): Application of Dye-Tracing Techniques for determining solute-transport characteristics of ground water In karst terranes.

UNITED STATES ENVIRONMENTAL PROTECTION AGENCY (EPA) (2003):Tracer-Test Planning Using the Eff icient Hydrology Tracer-Test Design /EHTD) Program. National Center for Environmental Assessment, Washington, DC;EPA/60o/R-03/034. 